\title{
AKTIVITAS DIURETIK KOMBINASI EKSTRAK BIJI PEPAYA (Carica papaya L) DAN BIJI SALAK (Salacca zalacca varietas zalacca (Gaert.)Voss) PADA TIKUS JANTAN GALUR WISTAR (Rattus norvegicus L)
}

\section{DIURETIC AKTIVITY OF SEED EXTRACT COMBINATION OF PAPAYA (Carica papaya L.) AND SNAKE FRUID (Salacca zalacca varietas zalacca (GAERT.)VOSS) IN WISTAR STRAIN MALE RATS (Rattus norvegicus L.)}

\author{
Nurihardiyanti $^{1{ }^{*},}$ Yuliet $^{1}$, Ihwan ${ }^{1}$ \\ ${ }^{1}$ Jurusan Farmasi Fakultas MIPA Universitas Tadulako, Palu
}

Received 28 Agustus 2015, Accepted 28 September 2015

\begin{abstract}
ABSTRAK
Telah dilakukan penelitian uji aktivitas diuretik kombinasi ekstrak biji pepaya (Carica papaya L) dan biji salak (Salacca zalacca (Gaert.) Voss) pada tikus jantan galur wistar (Rattus norvegicus L.). Penelitian ini bertujuan untuk mengetahui efek diuretik dan kombinasi dosis efektif sebagai diuretik. Ekstrak dibuat dengan metode maserasi menggunakan pelarut etanol 96\%. Uji aktivitas diuretik yang dilakukan dibagi dalam 5 kelompok perlakuan. Setiap kelompok terdiri dari 5 ekor tikus putih. Kelompok 1 (K1) (kontrol negatif) diberikan suspensi Na-CMC 0,5\%; K2 (kontrol positif) diberikan furosemid 3,6 mg/kgBB; serta K3, K4 dan K5 berturut-turut diberikan kombinasi dosis ekstrak biji salak dan biji pepaya secara berturut-turut sebesar " 37,5 $\mathrm{mg} / \mathrm{kgBB}+7,5 \mathrm{mg} / \mathrm{kgBB}$ "; "70 mg/kgBB + $15 \mathrm{mg} / \mathrm{kgBB}$ "; dan " $140 \mathrm{mg} / \mathrm{kgBB}+30 \mathrm{mg} / \mathrm{kgBB}$ ". Masing-masing tikus kemudian diberi aquadest hangat $\left(\right.$ suhu $\left.70^{\circ} \mathrm{C}\right) 10 \mathrm{ml} / 100 \mathrm{gBB}$ sebagai loading dose secara oral. Diukur volume urin yang dieksresikan dicatat tiap 30 menit selama 6 jam setelah itu dilanjutkan pengukuran volume urin kumulatif. Kemudian dari volume urin kumulatif diambil sampel untuk pengukuran kadar natrium $(\mathrm{Na})$, kalium (K), serta $\mathrm{pH}$ urin. Data dianalisis secara statistik menggunakan ANOVA (analysis of variance). Hasil penelitian menunjukkan bahwa kombinasi dosis ekstrak yang efektif adalah dosis K5 (ekstrak biji salak 140 $\mathrm{mg} / \mathrm{kgBB}$ dan biji pepaya dosis $30 \mathrm{mg} / \mathrm{kgBB}$ ) dengan indeks aktivitas diuretik sebesar 1,48; $\mathrm{pH}$ urin 7,52; indeks saluretik natrium sebesar 1,62 dan indeks saluretik kalium 1,56.
\end{abstract}

Kata kunci : biji pepaya, biji salak, diuretik, pH Urin, Natrium, Kalium.

\section{ABSTRACT}

Research on diuretic activity of seed extract combination of papaya (Carica papaya $\mathrm{L}$ ) and snake fruit (Salacca zalacca (Gaert.) Voss) to male wistar strain rats (Rattus norvegicus L.) has been conducted. This study aimed to determine the diuretic effect of the seed extract combination and its effective dose combination as diuretics. The extract was prepared by maceration method using ethanol $96 \%$. Diuretic activity test was divided into 5 treatment groups. Each group consisted of 5 rats. Group 1 (negative control) was given suspension of NaCMC 0.5\%; Group 2 (positive control) was given furosemide $3.6 \mathrm{mg} / \mathrm{kgBW}$; Group 3, 4, and 5 were given dose combination of snake fruit seed extract and papaya seed extract successively at " $37.5 \mathrm{mg} / \mathrm{kgBW}+7.5$ $\mathrm{mg} / \mathrm{kgBW}$ "; "70 mg/kgBW + 15mg/kgBW"; and "140 mg/kgBW + $30 \mathrm{mg} / \mathrm{kgBW}$ ". Each rat was then orally given warm distilled water $\left(70^{\circ} \mathrm{C}\right) 10 \mathrm{ml} / 100 \mathrm{gBW}$ as loading dose. The excreted urine volume was measured and recorded every 30 minutes for 6 hours which was continued to cumulative urine volume calculation. Furthermore, sample was taken from the cumulative urine to measure levels of sodium $(\mathrm{Na})$, potassium $(\mathrm{K})$, and the $\mathrm{pH}$ of the urine. Data were statistically analyzed using ANOVA (Analysis of Variance). The results showed that the effective extract dose combination was found in Group 5's dose $(140 \mathrm{mg} / \mathrm{kgBW}$ of snake fruit seed extract and $30 \mathrm{mg} / \mathrm{kgBW}$ papaya seed extract) with diuretic activity index of 1.48; urine $\mathrm{pH}$ of 7.52; sodium saluretic index of 1.62; and potassium saluretik index of 1.56 . 
Keywords: snake fruit seed, papaya seed, diuretics, urine $\mathrm{pH}$, sodium, potassium.

*Corresponding author : Nuriardiyanti, hjadawiah@gmail.com

\section{PENDAHULUAN}

Diuretik adalah obat yang dapat menambah kecepatan pembentukan urin. Istilah diuresis mempunyai dua pengertian, pertama menunjukkan adanya penambahan volume urin yang diproduksi dan yang kedua menunjukkan jumlah pengeluaran (kehilangan) zat-zat terlarut dan air. Fungsi utama diuretik adalah untuk memobilisasi cairan edema, yang berarti mengubah keseimbangan cairan sedemikian rupa sehingga volume cairan ekstrasel kembali menjadi normal (Tanu, 2009).

Diuretik berperan dalam penurunan tekanan darah yang terjadi setelah penggunaan senyawa ini berlangsung 2 fase. Penurunan tekanan darah mula-mula terjadi akibat peningkatan eksresi natrium. Konsentrasi ion natrium terjadi penurunan akibatnya volume plasma dan volume menit jantung akan turun, sebaliknya tekanan perifer (secara reflektoris) agak naik. Pada fase kedua, volume plasma akan dinormalkan kembali dan eksresi natrium akan hampir sama dengan harga awal terapi. Penurunan tekanan darah pada fase ini kemungkinan terutama disebabkan oleh kurangnya kandungan natrium dalam dinding pembuluh (Ernst Mutschler, 1991). Tetapi pada umumnya yang digunakan dalam menangani hipertensi adalah dengan menggunakan obat-obatan sintetis seperti furosemid (Tanu, 2009).

Selain menggunakan obat sintetis, beberapa obat herbal digunakan sebagai alternatif pengobatan. Pengobatan tersebut kebanyakan diperoleh berdasarkan pengetahuan masyarakat secara turuntemurun, namun sebagian besar tanaman obat yang ada belum terbukti khasiatnya secara ilmiah. Buah salak (Salacca zalacca (Gaert.) Voss.) dan pepaya (Carica papaya L.) merupakan buah khas dari Indonesia yang dapat ditemukan hampir disetiap daerah. Daging buah salak telah diproses menjadi berbagai macam produk olahan pangan dan banyak menghasilkan limbah biji salak. Pemanfaatan biji salak masih kurang karena bijinya yang keras dan tidak mudah hancur sehinggga untuk mengolah biji salak cukup sulit. Bijinya dibuang karena dianggap tidak bermanfaat namun seiring perkembangan teknologi pengetahuan maka biji salak telah diolah menjadi kopi oleh masyarakat di daerah Sumatera dan Jawa. Manfaat yang dirasakan setelah mengonsumsi biji salak yaitu adanya penurunan tekanan darah. Penurunan tekanan darah dapat berhubungan dengan terjadinya diuresis. Diuresis dapat menyebabkan penurunan volume plasma yang akan menurunkan curah jantung dan menurunkan tekanan darah.

Penelitian sebelumnya membuktikan bahwa ekstrak etanol biji salak pada dosis 0,14 $\mathrm{g} / \mathrm{kg} \mathrm{BB}$ sebanding dengan furosemid dapat meningkatkan volume urin selama 6 jam dan memberikan efek diuretik terhadap tikus putih jantan galur Wistar (Novita,dkk.,2014). Hal ini disebabkan karena adanya kandungan flavonoid yang berperan dalam meningkatkan volume urin (diuresis). Mekanisme kerja flavonoid sebagai diuretik dengan cara menghambat ko-transpor dan menurunkan reabsorbsi ion $\mathrm{Na}^{+}, \mathrm{K}^{+}$, dan $\mathrm{Cl}^{-}$terjadi peningkatan elektrolit di tubulus sehingga terjadilah diuresis (Geurin dan Reveillere, 1989).

Pemanfaatan biji pepaya juga sangat kurang karena memiliki biji yang kecil dan berbau tidak enak sehingga masyarakat hanya menjadikannya sebagai limbah padahal biji pepaya mempunyai manfaat. Menurut Villegas (1992) biji buah pepaya dapat digunakan sebagai obat peluruh kencing (diuretik). Penelitian oleh Isnania,dkk (2014) menyatakan bahwa pada ekstrak biji pepaya memiliki efek diuretik terhadap tikus putih jantan galur Wistar dengan efek terbaik ditunjukkan pada dosis $0,03 \mathrm{~g} / \mathrm{kgBB}$ sebanding dengan furosemid. Hasil skrining fitokimia menunjukkan ekstrak biji pepaya mengandung senyawa alkaloid. Alkaloid bekerja langsung pada tubulus dengan cara meningkatkan ekskresi $\mathrm{Na}^{+}$dan $\mathrm{Cl}^{-}$. Dengan meningkatnya ekskresi $\mathrm{Na}+$ juga akan meningkatkan ekskresi air dan menyebabkan volume urin bertambah (Nessa, 2013).

Berdasarkan uraian diatas, oleh karena belum adanya penelitian yang 
mengkombinasikan antara ekstrak biji salak dan ekstrak biji pepaya, maka peneliti tertarik ingin mengetahui efektivitas diuretik kombinasi ekstrak biji pepaya dan biji salak pada tikus putih jantan dan mengetahui adanya efek potensiasi serta menentukan kombinasi dosis ekstrak biji pepaya dan ekstrak biji salak yang mempunyai efek diuretik pada tikus putih jantan.

\section{METODE PENELITIAN}

Alat

Kandang hewan uji, sarung tangan, tempat makanan dan minum hewan uji, alatalat gelas $\left(\right.$ Pyrex $\left.^{\circledR}\right)$, rotary evaporator (Eyela OSB 2100), oven, pipet, pisau, ayakan, disposable syringe 1,5 dan $10 \mathrm{~mL}$, blender (Laboratory blender), gelas $\operatorname{kimia}\left(\mathrm{Pyrex}^{\circledR}\right)$, modifikasi kandang metabolit, kertas saring, masker, timbangan analitik, waterbath, wadah penampung urin, $\mathrm{pH}$ meter, sonde oral dan Flame Fotometer (BWBXP Flame Photometer).

\section{Bahan}

Biji salak dan biji pepaya. Bahan-bahan kimia yang digunakan etanol 96\%, akuades, $\mathrm{Na} \mathrm{CMC}$, Reagen Dragedorff, Wagner, Mayer, Lieberman Buchard, Furosemid (PT INDOFARMA No Batch 1505005), serbuk $\mathrm{Mg}$, asam klorida pekat, asam nitrat, asam perklorat, larutan $\mathrm{FeCl}_{3}, \mathrm{LaCl}_{3}$ dan $\mathrm{HCl} 2 \mathrm{~N}$.

Hewan uji yang digunakan dalam penelitian ini yaitu hewan tikus putih jantan galur Wistar dengan berat badan 180-220 g sebanyak 15 ekor. Sebelum dilakukan pengujian, hewan uji dikondisikan terlebih dahulu selama 1 minggu dengan kondisi lingkungan, makanan dan diberi minuman yang sama.

\section{Pembuatan Ekstrak Biji Pepaya dan Biji Salak Dengan Metode Maserasi}

Biji pepaya diekstraksi menggunakan pelarut etanol 96\%, pembuatan ekstrak dilakukan dengan metode maserasi, yaitu sebanyak $250 \mathrm{~g}$ serbuk biji pepaya yang diperoleh dimasukkan kedalam bejana maserasi kemudian ditambahkan pelarut etanol $96 \%$, ditutup dan dibiarkan terendam selama 3 hari terlindung dari cahaya (setiap hari digojok). Ekstrak kemudian disaring dengan menggunakan kertas saring sehingga didapat maserat (filtrat 1) dan residunya diremaserasi dengan etanol 96\% menggunakan prosedur yang sama, maserasi dilakukan selama 2 hari sampai diperoleh maserat yang jernih (filtrat 2). Selanjutnya semua maserat etanol digabungkan (filtrat 1+filtrat 2) dan diuapkan dengan menggunakan Rotary evaporator pada temperatur $40^{\circ} \mathrm{C}$ sampai volumenya menjadi $1 / 4$ dari volume awal dan dilanjutkan dengan pemekatan menggunakan waterbath pada suhu $40^{\circ} \mathrm{C}$ sehingga menghasilkan ekstrak kental.

Biji salak diekstraksi menggunakan pelarut etanol 96\%, pembuatan ekstrak dilakukan dengan metode maserasi, yaitu sebanyak 300 g serbuk biji salak yang diperoleh dimasukkan kedalam bejana maserasi kemudian ditambahkan pelarut etanol $96 \%$, ditutup dan dibiarkan terendam selama 3 hari terlindung dari cahaya (setiap hari digojok). Ekstrak kemudian disaring dengan menggunakan kertas saring sehingga didapat maserat (filtrat 1) dan residunya diremaserasi dengan etanol $96 \%$ menggunakan prosedur yang sama, maserasi dilakukan selama 2 hari sampai diperoleh maserat yang jernih (filtrat 2). Selanjutnya semua maserat etanol digabungkan (filtrat 1+filtrat 2) dan diuapkan dengan menggunakan Rotary evaporator pada temperatur $40^{\circ} \mathrm{C}$ sampai volumenya menjadi $1 / 4$ dari volume awal dan dilanjutkan dengan pemekatan menggunakan waterbath pada suhu $40^{\circ} \mathrm{C}$ sehingga menghasilkan ekstrak kental.

\section{Pengujian efek diuretik kombinasi biji pepaya dan biji salak}

Tikus dipuasakan tidak diberi makan \pm 18 jam dengan tetap diberi minum ad libitum, kemudian bobot badan tikus ditimbang. Dibagi menjadi 5 kelompok, masing-masing diberi aquadest hangat (suhu $70^{\circ} \mathrm{C}$ ) $10 \mathrm{ml} / 100 \mathrm{~g}$ sebagai loading dose secara oral.

Setelah 30 menit masing-masing tikus diberi perlakuan sesuai kelompoknya. Tikus kemudian ditempatkan di kandang metabolik individual dan volume urin yang diekskresikan dicatat setiap 30 menit selama 6 jam setelah itu dilanjutkan pengukuran volume urin kumulatif. Kemudian dari volume urin kumulatif diambil sampel untuk pengukuran kadar natrium $(\mathrm{Na})$, kalium $(\mathrm{K})$, serta $\mathrm{pH}$ urin. 
Tabel 1. Pembagian kelompok uji aktivitas diuretik kombinasi ekstrak biji pepaya dan biji salak

\begin{tabular}{|c|c|c|c|}
\hline No & Kelompok & $\begin{array}{l}\text { Jumlah } \\
\text { Tikus } \\
\text { (ekor) }\end{array}$ & Perlakuan \\
\hline 1 & $\begin{array}{l}\text { Kontrol } \\
\text { Negatif (-) }\end{array}$ & 5 & $\begin{array}{l}\text { Diberi suspensi } \\
\mathrm{Na} \text { CMC } 0,5 \%\end{array}$ \\
\hline 2 & $\begin{array}{l}\text { Kontrol } \\
\text { Positif (+) }\end{array}$ & 5 & $\begin{array}{l}\text { Diberi suspensi } \\
\text { furosemid } 3,6 \\
\mathrm{mg} / \mathrm{kg} \mathrm{BB}\end{array}$ \\
\hline 3 & $\begin{array}{l}\text { Kombinasi } \\
\text { Dosis } 1\end{array}$ & 5 & $\begin{array}{l}\text { Diberi suspensi } \\
\text { kombinasi ekstrak } \\
\text { biji salak } 37,5 \\
\text { mg/kg BB dan biji } \\
\text { pepaya } 7,5 \mathrm{mg} / \mathrm{kg} \\
\text { BB }\end{array}$ \\
\hline 4 & $\begin{array}{l}\text { Kombinasi } \\
\text { Dosis } 2\end{array}$ & 5 & $\begin{array}{l}\text { Diberi suspensi } \\
\text { kombinasi ekstrak } \\
\text { biji salak } 70 \\
\text { mg/kg BB dan biji } \\
\text { pepaya } 15 \mathrm{mg} / \mathrm{kg} \\
\text { BB }\end{array}$ \\
\hline 5 & $\begin{array}{l}\text { Kombinasi } \\
\text { Dosis } 3\end{array}$ & 5 & $\begin{array}{l}\text { Diberi suspensi } \\
\text { kombinasi ekstrak } \\
\text { biji salak } 140 \\
\mathrm{mg} / \mathrm{kg} \text { BB dan biji } \\
\text { pepaya } 30 \mathrm{mg} / \mathrm{kg} \\
\text { BB }\end{array}$ \\
\hline
\end{tabular}

\section{Pengukuran pH (Derajat Keasaman)}

Penetapan $\mathrm{pH}$ urin menggunakan $\mathrm{pH}$ meter. Untuk penetapan $\mathrm{pH}$ ini, urin harus benar-benar segar atau diawetkan supaya jangan terjadi amonia oleh perombakan ureum.

\section{Penentuan Kadar Natrium dan Kalium dengan Flame Fotometer}

Sebanyak $1 \mathrm{ml}$ volume urin diekstraksi dengan menambahkan asam nitrat $5 \mathrm{ml}$ ditambahkan asam perkolat $2 \mathrm{ml}$ selama 24 jam, kemudian dimasukkan dalam erlenmeyer $25 \mathrm{ml}$, selanjutnya didestruksi basah hingga volumenya 1-2 $\mathrm{ml}$ dan didinginkan hingga suhu ruang. dimasukkan kedalam labu terukur $25 \mathrm{ml}$ kemudian dicukupkan dengan aquades sampai $25 \mathrm{ml}$ ditambahkan larutan baku campuran $\mathrm{LACl}_{3} 4,5 \mathrm{ml}$, selanjutnya diukur menggunakan alat Flame Fotometer.

\section{Analisis Data}

Volume urin yang diperoleh digunakan untuk menghitung indeks aktivitas diuretik (IAD) berdasarkan persamaan. Persamaan tersebut diuraikan sebagai berikut.

$$
\mathrm{IAD}=\frac{\text { Volume Urin Kel.Bahan Uji }}{\text { Volume Urin Kel.Kontrol Negatif }}
$$

Data kadar natrium dan kalium digunakan untuk menghitung indeks saluretik.

Persamaan indeks saluretik disajikan sebagai berikut.

\section{$\mathrm{IS}=\frac{\text { Kadar Elektrolit Bahan UJi }}{\text { kadar Elektrolit Kelompok Kontrol Negatif }}$}

Selain itu volume urin kumulatif, kadar natrium dan kalium yang diperoleh dianalisis dengan menggunakan metode ANOVA (Analysis of Variance) pada tingkat kepercayaan 95\%. Dilanjutkan dengan uji Duncan untuk mengetahui kelompok perlakuan yang berbeda signifikan dibandingkan dengan yang lainnya. Data diolah dengan menggunakan SPSS Ver. 20.0.

\section{HASIL DAN PEMBAHASAN Hasil Penapisan Fitokimia}

Ekstrak etanol biji salak positif mengandung senyawa bioaktif yang berperan dalam memberikan khasiat atau efek biologi, antara lain flavonoid, alkaloid, saponin, dan tanin. Hasil penapisan fitokimia dapat dilihat pada Tabel 2.

Tabel 2. Hasil Penapisan Fitokimia Ekstrak Biji Pepaya

\begin{tabular}{llc}
\hline No. & Golongan Senyawa & $\begin{array}{c}\text { Hasil } \\
\text { Identifikasi }\end{array}$ \\
\hline 1. & Flavonoid & + \\
2. & Saponin & + \\
3. & Steroid/Triterpenoid & - \\
4. & Alkaloid & + \\
5. & Tanin & + \\
\hline
\end{tabular}

Keterangan :

(+) Ekstrak mengandung golongan senyawa yang diuji

(-) Ekstrak tidak mengandung golongan senyawa yang diuji 
Ekstrak etanol biji pepaya positif mengandung senyawa bioaktif yang berperan dalam memberikan khasiat atau efek biologi, antara lain flavonoid, alkaloid, saponin, dan tanin. Hasil penapisan fitokimia dapat dilihat pada Tabel 3.

Tabel 3 Hasil Penapisan Fitokimia Ekstrak Biji Salak

\begin{tabular}{llc}
\hline No. & Golongan Senyawa & $\begin{array}{c}\text { Hasil } \\
\text { Identifikasi }\end{array}$ \\
\hline 1. & Flavonoid & + \\
2. & Saponin & + \\
3. & Steroid/Triterpenoid & - \\
4. & Alkaloid & + \\
5. & Tanin & + \\
\hline
\end{tabular}

\section{Keterangan :}

(+) Ekstrak mengandung golongan senyawa yang diuji

(-) Ekstrak tidak mengandung golongan senyawa yang diuji

\section{Hasil Pengukuran Volume Urin dan Indeks Aktivitas Diuretik}

Hasil pengukuran volume urin kumulatif dan indeks aktivitas diuretik dapat dilihat pada Tabel 4.

Tabel 4. Volume total urin dan indeks aktivitas diuretik

\begin{tabular}{ccc}
\hline Kelompok & $\begin{array}{c}\text { Volume Total } \\
\text { Urin } \\
\text { (ml/6 jam) }\end{array}$ & $\begin{array}{c}\text { Indeks } \\
\text { Aktivitas } \\
\text { Diuretik }\end{array}$ \\
\hline $\begin{array}{c}\text { Kontrol Negatif } \\
\text { (Na CMC) } \\
\text { Kontrol Positif } \\
\text { (Furosemid) }\end{array}$ & $12,62 \pm 0,99^{\mathrm{a}}$ & - \\
Kombinasi Dosis 1 & $13,44 \pm 0,67^{\mathrm{a}}$ & 1,06 \\
$\begin{array}{c}\text { Kombinasi Dosis 2 } \\
\text { Kombinasi Dosis 3 }\end{array}$ & $16,12 \pm 1,84^{\mathrm{b}}$ & 1,28 \\
& $18,68 \pm 0,31^{\mathrm{c}}$ & 1,48 \\
\hline
\end{tabular}

Keterangan:

Kombinasi Dosis 1 = Kombinasi ekstrak biji salak 37,5 $\mathrm{mg} / \mathrm{kg}$ BB dan biji pepaya $7,5 \mathrm{mg} / \mathrm{kg}$ BB

Kombinasi Dosis $2=$ Kombinasi ekstrak biji salak 70 $\mathrm{mg} / \mathrm{kg}$ BB dan biji pepaya $15 \mathrm{mg} / \mathrm{kg} \mathrm{BB}$

Kombinasi Dosis $3=$ Kombinasi ekstrak biji salak 140 $\mathrm{mg} / \mathrm{kg}$ BB dan biji pepaya $30 \mathrm{mg} / \mathrm{kg} \mathrm{BB}$

\section{Hasil Pengukuran pH Urin}

Hasil pengukuran $\mathrm{pH}$ urin dilakukan dengan menggunakan alat $\mathrm{pH}$ meter. Hasil pengukuran $\mathrm{pH}$ urin dapat dilihat pada Tabel 5

Tabel 5. Hasil Pengukuran pH Urin

\begin{tabular}{cc}
\hline Kelompok & pH \\
\hline $\begin{array}{c}\text { Kontrol Negatif } \\
\text { (Na CMC) } \\
\text { Kontrol Positif } \\
\text { (Furosemid) } \\
\text { Kombinasi Dosis 1 }\end{array}$ & 7,17 \\
Kombinasi Dosis 2 & 7,29 \\
Kombinasi Dosis 3 & 7,48 \\
\hline
\end{tabular}

\section{Keterangan:}

Kombinasi Dosis $1=$ Kombinasi ekstrak biji salak 37,5 $\mathrm{mg} / \mathrm{kg}$ BB dan biji pepaya $7,5 \mathrm{mg} / \mathrm{kg} \mathrm{BB}$

Kombinasi Dosis $2=$ Kombinasi ekstrak biji salak 70 $\mathrm{mg} / \mathrm{kg}$ BB dan biji pepaya $15 \mathrm{mg} / \mathrm{kg}$ BB

Kombinasi Dosis $3=$ Kombinasi ekstrak biji salak 140 $\mathrm{mg} / \mathrm{kg}$ BB dan biji pepaya $30 \mathrm{mg} / \mathrm{kg}$ BB

\section{Hasil Pengukuran Kadar Natrium dan Kalium}

Hasil pengukuran kadar natrium dan kalium yang diperoleh dengan menggunakan alat flame fotometer, dapat dilihat pada Tabel 6.

Tabel 6. Nilai kadar natrium, kalium urin, dan indeks saluretik tikus

\begin{tabular}{ccccc}
\hline Kelompok & $\begin{array}{c}\text { Konsentrasi ion } \\
\mathbf{N a}^{+}(\mathbf{m E q} / \mathbf{L})\end{array}$ & $\begin{array}{c}\text { Konsentrasi ion } \\
\mathbf{K}^{+}(\mathbf{m E q} / \mathbf{L})\end{array}$ & $\begin{array}{c}\text { Indeks } \\
\text { Saluretik }\end{array}$ \\
\hline $\begin{array}{c}\text { Kontrol } \\
\text { Negatif (Na } \\
\text { CMC) }\end{array}$ & $1,00 \pm 0,02^{\mathrm{a}}$ & $0,51 \pm 0,07^{\mathrm{a}}$ & - & $\mathbf{N a}$ \\
\hline $\begin{array}{c}\text { Kontrol Positif } \\
\text { (Furosemid) }\end{array}$ & $4,26 \pm 0,05^{\mathrm{c}}$ & $1,91 \pm 0,04^{\mathrm{c}}$ & 4,25 & 3,74 \\
$\begin{array}{c}\text { Kombinasi } \\
\text { Dosis 1 }\end{array}$ & $1,51 \pm 0,10^{\mathrm{b}}$ & $0,74 \pm 0,04^{\mathrm{b}}$ & 1,5 & 1,43 \\
$\begin{array}{c}\text { Kombinasi } \\
\text { Dosis 2 }\end{array}$ & $1,55 \pm 0,06^{\mathrm{b}}$ & $0,73 \pm 0,01^{\mathrm{b}}$ & 1,55 & 1,43 \\
Kombinasi & $1,62 \pm 0,07^{\mathrm{b}}$ & $0,81 \pm 0,03^{\mathrm{b}}$ & 1,62 & 1,56 \\
Dosis 3 & & & & \\
\hline
\end{tabular}

Keterangan:

Kombinasi Dosis $1=$ Kombinasi ekstrak biji salak 37,5 mg/kg BB dan biji pepaya $7,5 \mathrm{mg} / \mathrm{kg}$ BB

Kombinasi Dosis $2=$ Kombinasi ekstrak biji salak $70 \mathrm{mg} / \mathrm{kg}$ $\mathrm{BB}$ dan biji pepaya $15 \mathrm{mg} / \mathrm{kg}$ BB

Kombinasi Dosis $3=$ Kombinasi ekstrak biji salak $140 \mathrm{mg} / \mathrm{kg}$ $\mathrm{BB}$ dan biji pepaya $30 \mathrm{mg} / \mathrm{kg} \mathrm{BB}$ 
Kandungan bioaktif yang terdapat dalam ektrak biji salak yang beraktivitas sebagai diuretik adalah flavonoid (Novita,dkk.,2014). Berdasarkan hasil penapisan fitokimia yang diperoleh menunjukkan bahwa pada ekstrak biji salak memberikan hasil positif terhadap golongan senyawa flavonoid, saponin, alkaloid dan tanin (Tabel 3). Sedangkan untuk kandungan bioaktif yang terdapat dalam ektrak biji pepaya yang beraktivitas sebagai diuretik adalah senyawa alkaloid (Nessa, 2013). Berdasarkan hasil penapisan fitokimia yang diperoleh menunjukkan bahwa pada ekstrak biji pepaya memberikan hasil positif terhadap golongan senyawa flavonoid, saponin, alkaloid dan tanin (Tabel 2). Penapisan fitokimia ini bertujuan untuk mengetahui golongan senyawa yang terkandung didalam ekstrak bahan uji yang digunakan.

Pada penelitian ini selang waktu pemberian semua perlakuan adalah 30 menit selama 6 jam. Sebelum diberi perlakuan terhadap masing-masing kelompok terlebih dahulu tikus putih jantan dicekok aquades hangat sebanyak $10 \mathrm{ml} / 100 \mathrm{~g}$ BB sebagai loading dose yang bertujuan merangsang pengeluaran urin serta untuk menyamakan kadar air dan garam elektrolit. Setelah 30 menit tikus putih jantan diberikan suspensi $\mathrm{Na}$ CMC 0,5\%, Furosemid, dan kombinasi ekstrak biji pepaya dan biji salak dengan selang waktu 30 menit dapat menimbulkan efek untuk meningkatkan volume urin. Pengukuran volume urin dilakukan selama 6 jam untuk melihat efek yang maksimal pada suatu bahan uji yang diberikan. Diuretik meningkatkan volume urin dan sering mengubah $\mathrm{pH}$-nya serta komposisi ion di dalam urin dan darah. Penggunaan klinis utamanya ialah dalam menangani kelainan yang melibatkan retensi cairan (edema) atau dalam mengobati hipertensi dengan efek diuretiknya menyebabkan penurunan volume darah, sehingga terjadi penurunan tekanan darah (Mycek, M. J., 2001).

Berdasarkan hasil pengukuran volume total urin tikus pada Tabel 4 menunjukkan bahwa pada kontrol negatif (Na CMC) memiliki volume urin yang rendah dibandingkan kontrol positif (Furosemid) dan kombinasi dosis 1, 2 dan 3. Hal ini disebabkan karena kontrol negatif tidak terkandung zat aktif yang dapat meningkatkan volume urin sehingga menyebabkan ekskresi urin yang keluar sedikit. Aktivitas diuretic tertinggi ke terendah secara berurutan adalah kombinasi dosis $3(1,48)$, furosemid 1,41), kombinasi dosis $2(1,28)$ dan kombinasi dosis $1(1,06)$. Peningkatan pemberian dosis ekstrak biji papaya dan ekstrak biji salak dapat meningkatkan pengeluaran volume urin terhadap tikus putih jantan. Hasil uji statistic Anova terhadap volume total urin diperoleh nilai signifikansi $0,000 \quad(\mathrm{p}<0,05)$. Artinya masing - masing perlakuan memberikan perbedaan yang bermakna, untuk hal ini maka perlu dilanjutkan dengan pengujian beda rata rata dari masing - masing perlakuan dengan uji Duncan. Hasil uji lanjut Duncan menunjukkan dari ketiga kombinasi dosis, kombinasi dosis 3 (ekstrak biji salak $140 \mathrm{mg} / \mathrm{kg}$ BB+ekstrak biji pepaya $30 \mathrm{mg} / \mathrm{kg} \quad \mathrm{BB}$ ) dan furosemid mempunyai efek yang sama dengan nilai signifikansinya adalah 0,203 yang masih lebih besar dari $(p>0,05)$. Sedangkan efek diuretik kombinasi dosis 1 lebih kecil bila dibandingkan dengan kombinasi dosis 2 dengan nilai signifikansi $0,01(\mathrm{p}<0,05)$ dan berbeda tidak signifikan dengan kontrol negative $(\mathrm{p}=0,224, \mathrm{p}>0,05)$, meskipun volume total urin kelompok kombinasi dosis 1 terlihat lebih banyak dibandingkan dengan control negative. Hal ini diduga karena konsentrasi zat aktif yang masih sedikit sehingga efek diuretik rendah.

Berdasarkan hasil pengukuran $\mathrm{pH}$ masing-masing kelompok menunjukkan adanya peningkatan derajat keasaman $(\mathrm{pH})$ urin. Nilai $\mathrm{pH}$ urin tikus normal berkisar 7,3 sampai 8. Nilai $\mathrm{pH}$ urin ditentukan oleh pengaturan asam basa di ginjal. Apabila sejumlah $\mathrm{HCO}_{3}{ }^{-}$difiltrasi secara terus menerus ke dalam tubulus ginjal dan dieksresikan ke dalam urin, maka akan menyebabkan urin bersifat basa. Sebaliknya, apabila sejumlah ion $\mathrm{H}^{+}$difiltrasi secara terus-menerus kedalam tubulus ginjal dan dieksresikan ke dalam urin maka akan menyebabkan urin bersifat asam (Brater DC, 1998). Dalam pengaturan konsentasi ion $\mathrm{H}^{+}$, ginjal memiliki beberapa mekanisme yaitu mensekresikan ion $\mathrm{H}^{+}$ke tubulus, melakukan reabsorbsi ion $\mathrm{HCO}_{3}{ }^{-}$dan memproduksi ion $\mathrm{HCO}_{3}{ }^{-}$yang baru. $\mathrm{Hal}$ ini dilakukan untuk mengurangi dan menetralisir kelebihan ion $\mathrm{H}^{+}$di dalam tubuh (Nalwaya $\mathrm{N}$, dkk. 2009).

Berdasarkan hasil pengukuran kadar natrium dan kadar kalium pada Tabel 6 . menunjukkan kadar natrium urin tikus yang 
diberikan kombinasi dosis ekstrak biji papaya dan ekstrak biji salak dengan tiga peringkat dosis yang digunakan cenderung meningkat seiring dengan bertambahnya dosis. Demikian juga halnya dengan kadar kalium urin yang diekskresikan. Berdasarkan hasil yang diperoleh, kombinasi dosis 1, 2 dan 3 menunjukkan efek diuretik terhadap kadar natrium dalam urin yang berbeda tidak signifikan. Pemberian kombinasi dosis 1,2 dan 3 mempunyai efek diuretik terhadap pengeluaran natrium lebih besar dibandingkan dengan tikus kontrol negatif tetapi tidak lebih banyak daripada kontrol positif dengan nilai signifikansi $0,00 \quad(\mathrm{p}<0,05)$. Hal ini menunjukkan bahwa furosemid lebih kuat untuk pengeluaran natrium dan kalium dalam urin tikus sedangkan CMC-Na $0,5 \%$ adalah sebagai kontrol negatif dalam penelitian ini memiliki urin dengan kandungan ion natrium dan kalium yang lebih rendah. Hal ini mengindikasikan bahwa peningkatan volume urin yang terlihat selama penelitian bukan merupakan efek osmotik atau aquaretik melainkan disebabkan oleh adanya aktivitas diuretik (Mary JM, dkk. 1995). Penelitian ini menunjukkan bahwa semakin banyak dosis ekstrak yang diberikan maka semakin banyak mempengaruhi pengeluaran volume urin dan ekskresi natrium. Peningkatan pengeluaran natrium dalam urin mengindikasikan adanya efek diuretik yang dihasilkan dari ekstrak biji papaya dan ekstrak biji salak. Hasil yang sama juga diperoleh pada pengukuran kadar kalium urin tikus.

Penelitian ini juga memberikan hasil bahwa kadar natrium dan kalium pada urin tikus lebih besar dari kadar kalium sesuai dari fungsi diuretik yang merupakan senyawa yang dapat meningkatkan pengeluaran ekskresi air dan garam-garam. Peningkatan kadar ion natrium dan kalium dalam urin pada kelompok tikus yang dicekok ekstrak biji pepaya dan biji salak ini merupakan efek natriuretik diuretik, hampir semua sediaan diuretik yang digunakan untuk menurunkan tekanan darah, gagal jantung dan memobilisasi ekskresi ion natrium dan kalium. Peningkatan kadar ion natrium dan kalium urin dimungkinkan diakibatkan oleh penghambatan karbonik anhidrase pada tubulus proksimal ginjal sehingga reabsorbsi ion natrium akan berkurang. Untuk menutupi kekurangan ion natrium dalam tubuh, ginjal memaksimalkan kerja ko-transport $\mathrm{Na}-\mathrm{K}$ di tubulus proksimal. Hasil kompensasi yang dilakukan oleh ginjal menyebabkan peningkatan kadar kalium di dalam urin (Lork S, 2006). Kemungkinan penyebab kenaikan kadar ion natrium dan kalium pada segmen asenden ansa henle sebagaimana mekanisme kerja furosemid (obat diuretik yang sering digunakan sebagai standar pembanding dalam pengujian diuretik) dan penghambatan reabsorbsi ion natrium pada tubulus distal (Mary JM, dkk. 1995). Ekskresi ion natrium dan kalium melalui urin secara terus menerus dapat mengakibatkan gangguan homeostasis ion di dalam tubuh, dehidrasi ion, dan pada kondisis kronis mengganggu kerja jantung. Oleh karena itu penggunaan kombinasi ekstrak biji pepaya dan biji salak sebagai diuretik alami disarankan untuk digunakan sesuai dengan dosis efektif yang direkomendasikan.

Analisis fitokimia ekstrak etanol biji pepaya dan biji salak menunjukkan bahwa ekstrak tersebut mengandung alkaloid, flavonoid, saponin, dan tanin (Tabel 2 dan 3). Alkaloid merupakan senyawa organik terbanyak ditemukan di alam. Alkaloid golongan kafein, teobromin, dan teofilin memiliki khasiat diuretika (Lork S, 2006). Sementara itu flavonoid merupakan golongan fenol alam terbesar yang diketahui mempunyai berbagai khasiat, seperti antiradang, diuretik, antihipertensi, dan meningkatkan kerja pembuluh darah kapiler (Depkes, 2007). Alkaloid dapat memberikan efek diuretik dengan cara berikatan dengan reseptor adenosin A1. Alkaloid juga dapat menyebabkan peningkatan volume urin. Alkaloid bekerja langsung pada tubulus dengan cara meningkatkan ekskresi $\mathrm{Na}^{+}$dan $\mathrm{Cl}^{-}$. Dengan meningkatnya ekskresi $\mathrm{Na}^{+}$juga akan meningkatkan ekskresi air dan menyebabkan volume urin bertambah. Flavonoid dapat meningkatkan volume urin dengan cara meningkatkan laju kecepatan glomerulus (Jouad, 2001). Selain itu flavonoid dapat menghambat reabsorbsi $\mathrm{Na}^{+}$dan $\mathrm{Cl}^{-}$ sehingga menyebabkan peningkatan $\mathrm{Na}^{+}$dan air dalam tubulus. Dengan demikian, terjadi peningkatan volume air dalam tubulus dan terjadi peningkatan volume urin.

Saponin merupakan senyawa hasil metabolisme sekunder pada beberapa tanaman bersifat menurunkan tegangan permukaan, merangsang ginjal untuk bekerja lebih aktif, dan meningkatkan absorbsi diuretik (terutama bentuk garam dalam urin) (Nalwaya N, dkk. 2009). Dengan demikian, kandungan alkaloid, 
flavonoid, dan saponin yang terkandung dalam ekstrak etanol biji pepaya dan biji salak diduga bekerja sinergis menimbulkan efek diuretik.

Penggunaan kombinasi ekstrak biji pepaya dan biji salak sebagai diuretik alami telah terbukti mampu meningkatkan volume urin, eksresi ion natrium dan kalium melalui urin sehingga ekstrak ini memiliki potensi yang hampir sama dengan diuretik sintetik yang banyak digunakan saat ini. Pengeluaran ion natrium dan kalium dalam jumlah yang berlebih mengakibatkan dehidrasi, gangguan keseimbangan ion tubuh, dan pada kondisi yang parah dapat mengganggu fisiologis jantung. Dengan demikian, penggunaan kombinasi ekstrak biji pepaya dan biji salak sebagai diuretikum juga harus berhati-hati, tidak boleh diberikan secara terus menerus, dan sesuai dosis efektif sehingga meminimalisir efek negatif yang ditimbulkan.

\section{DAFTAR PUSTAKA}

Brater, D.C. (1998). Diuretic Theraphy. The New England Journal of medicine.

Depkes. (2007). Kebijakan Obat Tradisional Nasional, Departemen Kesehatan RI, Jakarta.

Geurin, J.C., and Reveillere H.P. (1989). Orthosiphone stamineus as a potent source of methylripario chromene A, J. Nat. Prod.

Isnania., dkk. (2014). Aktivitas Diuretik dan Skrining Fitokimia Ekstrak Etanol Biji Pepaya (Carica papaya L.) Pada Tikus Putih Jantan Galur Wistar (Rattus norvegicus) Jurnal Ilmiah Farmasi FMIPA Universitas Samratulangi Manado.

Jouad, H., Lacaille-Dubois MA., Lyoussi B, Eddouks M. (2001). Effects of The Flavonoids Extracted from Spergularia purpurea Pers. on Arterial Blood Pressure and Renal Function in Normal and Hypertensive Rats. Journal of Ethnopharmacology

Lork, S. (2006). Pemanfaatan Obat Tradisional dengan Pertimbangan Manfaat dan Keamanannya, Majalah Kefarmasian.

Marry, JM, dkk. (1995). Farmakologi Ulasan Bergambar. Penerbit Widya Medika, Jakarta.

Mycek, M. J., Harvey, R. A., dan Champe C.C. (2001). Farmakologi Ulasan Bergambar, Edisi 2. Penerbit Widya Medika. Jakarta.

Mutschler Ernst. (1991). Dinamika Obat. Edisi 5. Penerjemah Mathilda B Widianto, Anna Setiadi Ranti. ITB. Bandung.

Nalwaya N, dkk. (2009). Diuretic activity of a herbal product UNEX. International Journal of Green Pharmacy.

Nessa. (2013). Efek Diuretik dan Daya Larut Batu Ginjal dari Ekstrak Etanol Rambut Jagung (Zea mays L.). Fakultas Farmasi, Universitas Andalas. Padang.

Novita., dkk. (2014). Uji Efektivitas Diuretik Ekstrak Etanol Biji Salak (Salacca zalacca varietas zalacca (gaert) Voss) Pada Tikus Putih Jantan Galur Wistar (Rattus norvegicus) Jurnal Ilmiah Farmasi FMIPA Universitas Samratulangi Manado.

Tanu, I. (2009). Farmakologi dan Terapi Edisi 5 (Cetak Ulang dengan Perbaikan), Balai Penerbit FKUI, Jakarta

Villegas, V.N. (1992). Carica papaya L. Didalam Verheij EWM dan CoroneRE, editor Plant Resources of South-East Asia: Edible Fruits and Nuts No.2. PROSEA Foundation. Bogor. 